\title{
elyra
}

\section{Um vampiro tropicalista: A poética antropofágica de Torquato Neto}

\author{
Elzimar Fernanda Nunes Ribeiro / Pâmella Pereira Magalhães \\ Universidade Federal de Uberlândia - UFU
}

Resumo: Torquato Neto foi um importante divulgador da Antropofagia cultural, elaborada por Oswald de Andrade, entre a geração estética da Tropicália. Torquato foi, ele mesmo, um poeta altamente antropofágico, tendo criado sua obra através da absorção de estilos e imagens provenientes de outros autores. Este aspecto devorador se mostra coerente com a identidade vampiresca que ele construiu para si, em suas diversas manifestações artísticas. O presente trabalho examina a relação que sua poesia estabelece com os textos vítimas, concluindo que Torquato emprega o vampirismo literário como modo de afirmação existencial e estética.

Palavras-chave: Antropofagia cultural, sujeito poético, Tropicália

\begin{abstract}
Torquato Neto was an important divulgator of the Cultural Anthropophagy, elaborated by Oswald de Andrade, among the esthetic generation called as Tropicalia. Torquato himself was a highly anthropophagical poet by creating his work through the absorption of styles and imageries from other authors. This aspect of devourer reveals coherent with the vampiric identity that he boiled for himself, in his several artistic manifestations. This issue examines the relation that his poetry establishes with the victim texts, concluding that Torquato uses the literary vampirism as a way of existential and esthetical affirmation.
\end{abstract}

Keywords: Cultural Anthropophagy, poetic subject, Tropicalia 
Só me interessa o que não é meu. Lei do homem. Lei do antropófago

O poeta piauiense Torquato Neto é conhecido como um dos principais integrantes da Tropicália, movimento estético fortemente devedor da proposta antropofágica de Oswald de Andrade, cuja verve de irreverente criatividade inspirou toda uma geração de jovens artistas dispostos a empreender uma renovação da arte brasileira, mesmo em plena Ditadura Militar.

Implantado em 1964, o regime totalitário valia-se de violência física e simbólica, no intuito de formar um cidadão de acordo com seu ideário, "o que significava banir da mentalidade dos brasileiros todo e qualquer espírito de oposição e/ou contestação" (Rezende 2001: 82). De modo que o caráter opressor do governo ditatorial foi um obstáculo considerável aos novos artistas brasileiros de então - ironicamente estimulados pelo mesmo espírito contestador que distinguiu vários movimentos juvenis dos países ocidentais, durante os anos de 1960 e 1970. O primeiro período da Ditadura Militar, entre 1964 e 1968, também foi marcado pelos festivais de música popular, espaço significativo de divulgação de ideias, uma vez que estava diretamente ligado ao crescente poderio da indústria cultural brasileira (conjugando diversas mídias como rádio, televisão e indústria fonográfica) e ainda se encontrava relativamente livre dos censores do governo. O próprio Torquato encontrou seu lugar ao sol neste ambiente, gozando da condição de quase famoso, graças a sua reputação de letrista - sobretudo após "Louvação", canção composta em parceria com Gilberto Gil, causar comoção no Festival Internacional da Canção de 1966.

Embalados pela grande projeção que os festivais Ihe proporcionaram, vários destes jovens artistas envolveram-se com a proposta ainda mais subversiva da Tropicália, buscando seu espaço nas frestas mais frouxas do sistema. Durante o ano de 1967, diversos acontecimentos no mundo das artes em geral semearam o germe do novo movimento estético. Torquato estava muito próximo de todos os mais importantes focos do debate criativo que originou o Tropicalismo, tais como a cena de experimentação teatral do grupo Oficina ou as exposições de artes plásticas do seu amigo íntimo e grande interlocutor Hélio 
Oiticica. Mas, sobretudo, ele continuava suas parcerias musicais com Gil e Caetano Veloso, estrelas do festival de música daquele ano, frente mais visível do movimento diante do grande público.

Embora tenha tido momentos de articulação coletiva mais patentes, o Tropicalismo era de fato bastante heterogêneo, a tal ponto que, por diversas vezes, alguns de seus participantes negaram-lhe o caráter de movimento ou de grupo articulado. Importante precursor dos estudos sobre o tema, Celso Favaretto (2000) falava desde o início em "mistura tropicalista" e analisava o vínculo entre a Tropicália e a Antropofagia oswaldiana, citando Caetano Veloso em epígrafe, "O tropicalismo é um neo-antropofagismo", e assinalando os procedimentos de devoramento estético postos em prática pelos tropicalistas:

O tropicalismo evidenciou o tema do encontro cultural e o conflito das interpretações, sem apresentar um projeto definido de superação; expôs as indeterminações do país no nível da história e da linguagem, devorando-as; reinterpretou em termos primitivos os mitos da cultura urbano-industrial, misturando e confundindo seus elementos arcaicos e modernos, explícitos ou recalcados, evidenciando os limites das interpretações em curso. (2000: 55-56)

Enfim, uma geleia geral, como tantas vezes reiteraria Torquato em expressão consagrada, que inclusive deu nome ao hino tropicalista que ele compôs com Gilberto Gil para o álbum-manifesto Tropicália ou Panis et Circensis, lançado em 1968, no qual participaram os mais importantes músicos e compositores do movimento. Valendo-se da premissa de que a estética tropicalista se pauta, principalmente (mas não unicamente), pela mistura e pelo confronto de componentes advindos da cultura de elite e da cultura de massa, podemos tomar esta canção como exemplar das propostas da Tropicália.

O título mesmo já era uma apropriação de uma frase do poeta concreto Décio Pignatari: "Alguém tem que fazer o papel de medula e osso na geleia geral brasileira", como Torquato nunca se negou a explicitar (Neto 2004b: 375). Os primeiros versos da canção ganham ares de manifesto, ao anunciarem: "Um poeta desfolha a bandeira e a manhã tropical se inicia" (Neto 2004a: 126); e o refrão de "Geleia geral" prossegue: "Ê bumba iê, iê boi / Ano que vem mês que foi/ Ê bumba iê, iê iê/ É a mesma dança meu boi" (ibidem). Destaca-se aqui a união de aparentes divergências, com a aproximação inusitada entre a 
tradicional dança folclórica do Bumba Meu Boi e o recém-chegado ritmo do "iê-iê-iê" nome dado ao rock brasileiro dos anos de 1960 pela indústria fonográfica da época, com o intuito de facilitar a divulgação do produto musical estrangeiro por um Brasil ainda pouco habituado a anglicismos (a expressão era uma corruptela do grudento refrão "yeah, yeah, yeah", da canção "She loves you", dos então iniciantes The Beatles).

A composição de Torquato e Gil insinua, portanto, as similaridades entre o ritmo aborígene e o ritmo alienígena: "é a mesma dança meu boi", ao que responde o maestro Rogério Duprat colocando-os em diálogo na instrumentação musical tanto quanto na letra da canção. O burlesco trecho declamatório salienta a analogia: "É a mesma dança na sala/ No Canecão na TV" (ibidem), para a seguir fazer uma clara referência aos festivais de música do período, palco de tantas disputas entre a música brasileira tradicional e o rock, agora unificados na geleia geral das composições tropicalistas: "E quem não dança não fala/ Assiste a tudo e se cala/ Não vê no meio da sala/ As relíquias do Brasil:/ Doce mulata malvada,/ Um elepê de Sinatra/ Maracujá, mês de abril/ Santo barroco baiano,/ superpoder de paisano,/formiplac e céu de anil/ Três destaques da Portela,/carne-seca na janela,/ alguém que chora por mim (idem: 126-127).

Em tom laudatório embebido em autoironia, que satirizava o ufanismo característico do discurso da Ditadura Militar, a letra da canção exaltava a miscelânea de elementos por si mesmos já previamente marcados pelo hibridismo cultural: a mulata brasileira, o barroco baiano, o jazz urbano e mass-media do ítalo-americano Frank Sinatra, o desfile das escolas de samba do Rio de Janeiro e até uma empresa carioca especializada na fabricação de laminados imitando madeira (Formiplac). Tudo isso se encontra numa espécie de amálgama universal, um caldeirão onívoro que definiria a cultura brasileira como uma mistura de misturas, cuja exaltação, no entanto, é toda entrecortada por alusões ao nacionalismo totalitarista do regime de 1964.

Fredric Jameson (1985) entende que o pós-modernismo expressa a realidade intrínseca ao que ele denomina de "capitalismo tardio", o qual tem como pano de fundo uma sociedade pós-industrial ou de consumo, sociedade de mídia ou dos espetáculos. Segundo Jameson, o pós-modernismo propõe um abrandamento das fronteiras entre a alta cultura, a cultura popular e a chamada cultura de massa. A maior parte das manifestações 
pós-modernistas emerge contra algumas formas de modernismo canônico que haviam conquistado as universidades e espaços de exposição de arte. Os artistas pós-modernistas, diferentemente dos modernistas (que produziam uma arte ainda voltada sobretudo à elite e às instituições acadêmicas), incorporam às suas criações textos considerados subliteratura, tais como, anúncios, biografia popular, mistérios policiais, ficção científica etc.

Sendo assim, pode-se perceber que, em muitos aspectos, a poética que Torquato propõe, no âmbito da Tropicália, assume marcas e elementos típicos da estética pósmoderna, dentre os quais se destacam a fusão entre alta cultura e cultura de massas, o intenso uso da intertextualidade e o humor derrisório. A partir da proposta antropofágica, os tropicalistas encontraram uma base reflexiva e intelectual que Ihes permitia a incorporação crítica dos produtos da indústria cultural, justificando a partir daí a presença de uma multiplicidade de elementos nas obras tropicalistas advindos do cinema, da televisão, da publicidade e de outros discursos típicos da comunicação em massa. Segundo Favaretto "Ao participar de um dos momentos mais criativos da sociedade, os tropicalistas assumiram as contradições da modernização, sem escamotear as ambiguidades implícitas em qualquer tomada de posição" (2000: 25)

Favaretto entende que a Antropofagia serviu assim como um ponto de fuga, uma alternativa bem-vinda ao conflito gerado a partir das interpretações do Brasil propostas por um nacionalismo purista, em grande parte elaborado pela inteligentsia do Modernismo brasileiro e amplamente posto a favor dos discursos políticos de vários matizes ideológicos, ao longo do século XX. Como corrobora Andrade: "No jogo intertextual parodístico do ritual tropicalista é visível a presença do legado antropofágico, que se contrapõe aos discursos nacionalistas, adotados, naquele momento, tanto pela esquerda quanto pela direita" (2002: 71). Deste modo, por exemplo, não se precisaria mais ter de optar pela viola ou pela guitarra elétrica (dilema que chegou a provocar, ainda em 1967, uma Passeata Contra a Guitarra Elétrica), pelo samba ou pelo rock, pelo folclore brasileiro ou pelos filmes de Hollywood: a Tropicália juntava tudo com desembaraçado entusiasmo.

A frouxidão e miscelânea do projeto tropicalista incomodou parte considerável da crítica, do público e mesmo dos artistas, sobretudo uma parcela que vinha de um profundo compromisso com a arte engajada, como testemunha Heloísa Buarque de Hollanda (2004). A 
estudiosa ainda apresenta Torquato Neto como um símbolo maior do "desbunde" tropicalista, que trocou os racionalismos políticos e estéticos da geração imediatamente anterior (concretistas e engajados) pela irracionalidade da poesia vivenciada como loucura, como um transe criativo - agora alimentada por diversas substâncias psicotrópicas (idem: 81). No entanto, Torquato se sentia à vontade com a malemolência estético-ideológica do movimento, inclusive justificando sua preferência pela denominação Tropicália (e não Tropicalismo), uma vez que esta pressupunha uma maior abertura para a busca estética individual e autônoma dos artistas ligados ao grupo. A declaração faz parte de um manifesto pessoal do poeta, justamente denominado Torquatália III:

escolho a tropicália porque não é liberal, mas porque é libertina. a antifórmula superabrangente: o tropicalismo está morto, viva a tropicália. todas as propostas serão aceitas, menos as conformistas. (seja marginal). todos os papos, menos os repressivos (seja herói). e a voz de ouro do brasil canta para você. (Neto 2004a: 63)

Essa miscelânea cultural também dá o tom em "Marginalia II", poema musicado por Gilberto Gil. Aqui, é possível observar com grande clareza a habilidade com que Torquato decalca elementos provenientes de outros textos, moldando-os segundo seu intento expressivo, bem atento à lição da antropofagia oswaldiana. Dois textos de vocação patriótica, provenientes de diferentes posições na cadeia de produção cultural, são apropriados e desarticulados na letra de "Marginalia II". De um lado, tem-se "Canção do exílio", um dos textos mais emblemáticos do nacionalismo literário brasileiro: "Minha terra tem palmeiras, / Onde canta o sabiá;/ As aves que aqui gorjeiam, / não gorjeiam como lá". Nas estrofes torquatianas, a paisagem tropical, cantada pelo poema romântico de Gonçalves Dias, ganha o contraponto terrificante da miséria e da violência cotidianas da realidade social do país: "Minha terra tem palmeiras/ Onde sopra o vento forte/ Da fome do medo e muito/ Principalmente/ Da morte/ O-lelê, lalá" (Neto 2004a: 125).

De outro lado, à apropriação paródica da "Canção do exílio", Torquato soma ainda o empréstimo do lema "Yes nós temos bananas", que transitou por inúmeras produções da indústria cultural brasileira e internacional. Sua origem se deu em "Yes! We have no bananas" ["Sim! Nós não temos bananas"], título de um hit da Brodway, composto por Frank 
Silver e Irving Cohn, em 1922. A canção norte-americana era uma reclamação, algo cômica, sobre os problemas de abastecimento dos países de inverno rigoroso; em contraposição, a versão ufanista brasileira - "Yes, nós temos bananas" - exaltava a fartura da natureza dos trópicos. Composta por Alberto Ribeiro e João de Barro (o "Braguinha"), foi um imenso sucesso na voz de Carmen Miranda que, fechando o ciclo, interpretou também a versão em inglês quando de sua entrada no cinema norte-americano: "Yes, nós temos banana/ Banana pra dar e vender/ Banana, menina tem vitamina/ Banana engorda e faz crescer".

Mais uma vez, Torquato elabora um discurso poético em que a ode nacionalista é fraturada pela crítica social e política que o permeia. Se a fórmula "Yes nós temos bananas" fora bastante emitida como uma declaração de abundância tropical, em "Marginalia II", a fórmula ressurge alterada, e mal se disfarça o escárnio triste com que o Brasil é visto como nação subserviente no jogo político internacional. A despeito das ilusões de grandeza vendidas pelo governo militar, o país permanece como uma nação marginal, absolutamente impotente para definir os rumos assustadores da Guerra Fria, que então se desenrolava em seus momentos mais angustiantes: "A bomba explode lá fora/ E agora, o que vou temer?/ Yes: nós temos banana/ Até pra dar/ E vender" (Neto 2004a: 125).

Paradoxalmente, mesmo estando no "fim do mundo", em termos políticos e sociais, não é o Brasil que decide quando e como se dá o fim do mundo: "Aqui é o fim do mundo/ Aqui é o fim do mundo/ Ou lá" (ibidem). No avesso do mito da fartura natural, a tropicalidade brasileira se revela sombria e indigente: “Eu, brasileiro, confesso/ Minha culpa, meu degredo/ Pão seco de cada dia/ Tropical melancolia/ Negra solidão" (idem, 124), concebendo um lamento a partir do que antes fora uma marchinha carnavalesca nacionalista.

Tanto em "Marginalia II" quanto em "Geleia geral" - tomadas aqui como obras exemplares do período tropicalista de Torquato - o poeta recorta e remonta livremente, em novo contexto, citações, lemas, blagues. Torquato compõe a partir daí uma paisagem poética dinâmica, multifacetada, barulhenta, algo caótica, em que múltiplas vozes povoam o texto, confrontando-se, contrapondo-se, renegando-se, entredevorando-se.

Affonso Romano de Sant'Anna assinala a origem dadaísta da noção de colagem como técnica de composição, a qual veio a ser amplamente difundida pelas artes plásticas ao 
longo do século XX, principalmente no seio da pop art da década de 1960, por meio de artistas como Andy Warhol e Daniel Spoerri - contemporâneos da Tropicália. Na concepção de Sant'Anna, a colagem ou assemblage (reunião, ajuntamento) é uma forma de apropriação, assim definida: "na apropriação o autor não 'escreve', apenas articula, agrupa, faz bricolagem do texto alheio. Ele não escreve, ele trans-creve, colocando os significados de cabeça para baixo" (2003: 46). Não significa que não haja ação criativa do artista, cuja intervenção é fundamental para que se obtenha o efeito desejado, em que o texto original sofre um deslocamento e assume novos sentidos.

De fato, a colagem inventiva de Torquato permite a convivência entre mundos díspares, colocando para dialogar entre si elementos de origens e intenções muito diversas, provocando uma familiaridade inusitada, que afrontava os padrões discursivos estabelecidos no Brasil ufanista da Ditadura Militar. Tais características nos remetem ao conceito de paródia definido por Mikhail Bakhtin $(1981,1993)$, que pensa o texto paródico como um duplo rebaixador do texto original, isto é, um texto que reproduz o pensamento alheio de tal modo que suas falhas fiquem expostas e assim possam provocar o riso questionador, que não deixa nenhum ponto de vista se estabilizar na posição de verdade absoluta.

De acordo com Favaretto, a prática da colagem (por ele denominada de justaposição) não era apenas comum entre os tropicalistas, ela seria mesmo o procedimento central, o princípio articulador e identificador da forma de criação proposta pela Tropicália:

Quando justapõe elementos diversos da cultura obtém uma suma cultural de caráter antropofágico, em que contradições históricas, ideológicas e artísticas são levantadas para sofrer uma operação desmistificadora. Esta operação, segundo a teorização oswaldiana efetua-se através dos elementos contraditórios - enquadráveis basicamente na oposição arcaico-moderno, local-universal - e, que ao inventariá-las, as devora. Este procedimento do tropicalismo privilegia o efeito crítico que deriva da justaposição destes elementos. (2000: 26)

No entanto, a Tropicália teve vida curta, podada que foi, ainda no nascedouro, pelo governo militar. No final de 1968, publicou-se o Ato Institucional nํ5, instrumento jurídico que embasou a radicalização do regime implantado em 1964. Retirando direitos civis básicos de um regime minimamente democrático, o $\mathrm{Al}-5$ preparou "o cenário para os crimes da ditadura". O Estado ditatorial não demorou em voltar seu poderio contra tanto atrevimento 
e desassombro. Dentro de um par de anos, os tropicalistas mais ativos tomaram o caminho do exílio político para fugir às ameaças veladas ou escancaradas das forças repressoras. Em consequência, estava desmontada a Tropicália enquanto movimento coletivo, com cada artista tentando refazer sua vida do jeito que podia.

Considerado por muitos de seus contemporâneos como uma espécie de poeta maldito, Torquato teve mais dificuldades para sobreviver ao isolamento do exílio; como não era instrumentista ou cantor, mas um poeta que compunha canções em parceria com músicos, dispunha de muito menos margem de manobra. Pouco reconhecido pelo público geral e agora afastado de seus parceiros mais famosos (Caetano Veloso e Gilberto Gil), Torquato não tinha grande valor para a indústria cultural e sua situação financeira rapidamente tornou-se insustentável, especialmente diante da notícia da gravidez de sua mulher, a jornalista Ana Maria.

Por isso, Torquato optou por voltar ao Brasil, em 1970, em meio aos Anos de Chumbo, quando todos os que anteriormente haviam se insurgido contra a Ditadura estavam fazendo o possível para fugir do país. Mesmo diante do exíguo ambiente de expressão, Torquato não estava disposto a ceder às pressões do silenciamento imposto pela Ditadura e buscava encontrar meios que the possibilitassem desenvolver sua criação artística, segundo seus próprios desígnios. Seus esforços neste sentido levaram-no à condição de precursor da poesia marginal, que caracterizaria grande parte da cena poética brasileira da década de 1970 - caminho explorado por artistas que buscavam escapar às garras do sistema por meio de recursos artesanais, tais como poemas mimeografados ou filmes realizados em Super-8.

Num desses filmes underground, realizado pelo cineasta Ivan Cardoso, o poeta fazia as vezes de ator, interpretando um vampiro tropical que percorria a orla carioca e atacava seus frequentadores com toques de perversidade e humor nonsense. 0 título da obra era Nosferato no Brasil e a interpretação deste personagem foi um marco na vida de Torquato, que passou a incorporar o mito e a personalidade vampiresca como parte de sua identidade estética. Afinal, o vampirismo vinha a calhar com a aura maldita que naquele momento já começava a definir o artista; por outro lado, desde sempre ele praticara uma estética devoradora, ora apropriando-se de textos alheios, ora fazendo transitar trechos de textos 
seus entre os diversos gêneros em que se expressou: poema, canção, diário, cartas ou crônicas jornalísticas, roteiros, anotações de projetos inacabados.

É importante ressaltar que Torquato nunca chegou a organizar sua produção, deixando-a espalhada por jornais, cadernos, discos, correspondências e diários. As obras a que se tem acesso são uma compilação dos textos deixados pelo autor. A primeira publicação póstuma das obras de Torquato deu-se com Os últimos dias de Paupéria, compilação que teve forte repercussão nos anos de 1970, dando a Torquato uma aura de mártir da Ditadura. Uma segunda publicação da obra torquatiana - mais completa, por trazer vários textos, ainda inéditos, somados a toda sua produção cronística publicada em jornais - veio à luz somente em 2004, tendo sido organizada por Paulo Roberto Pires. Ao trazer à luz poemas inéditos da juventude do poeta, a compilação de Pires permite repensar algumas das características que vêm sendo atribuídas a Torquato pela crítica.

Assim, é possível surpreender em seus primeiros poemas, a presença marcante do exercício da colagem, o qual se revela um padrão de composição recorrente na obra do artista, que afinal fora leitor cuidadoso de Oswald desde muito jovem. Coloca-se então a questão sobre que papel(éis) a prática da colagem assume na poética torquatiana, quando esta se coloca à parte da missão tropicalista. Que sentidos e dimensões a absorção do texto alheio ganha na produção artística tão variada de Torquato Neto?

Seus primeiros poemas registrados já estabeleciam aberto diálogo com os autores que o poeta leu avidamente ainda nos seus anos de formação. Assim, por exemplo, no poema da juventude "Poeminha só de brincadeira", datado de 1961, ele explicita sua dívida com Homero e, mais sutilmente, se apropria de Lewis Carroll. A primeira estrofe do poema de versos curtos e acentuada aliteração narra, com entonação cômica, a mal sucedida aventura de um rapaz apaixonado, dispensado pela amada, que não o recebe em casa: "Sacro/ sacripanta / sem sal / e sem ponta/ arrufa / na porta /da casa/ da moça / da dona/ da casa / (sem asa)/ com brasa/ que vaza/ vazando... vazando/ sumindo." (Neto 2004a: 40). É previsível que o eu-poético se encarregue de chorar a desilusão amorosa, no entanto, as próximas estrofes do poema dão mais ênfase a outra perda: a perda do ideal romântico de originalidade poética: “(Oh! Mero/ imitador/ de Homero/ o grego/ da história/ da guerra/ de Troia). // Helena,/ Verbena/ tem pena/ de mim" (ibidem). 
A fala entre parênteses, na terceira estrofe, apresenta intrigantes possibilidades de leitura, afinal a quem pertenceria tal voz? À ingrata amada, que além de indiferente afetivamente ainda se mostraria uma cruel crítica literária, atacando os versos "sem sal" do pobre galanteador, que então Ihe pede misericórdia ("Helena,/ Verbena/ tem pena/ de mim.")? Ou pertenceria esta voz à plateia implacável, numa atualização do coro das tragédias gregas, representando a opinião pública revoltada com o desaforo do moço de se passar por poeta ("sacripanta")? Ou, enfim, talvez seja a ferrenha autoconsciência do artista, a inscrever no texto a experiência excruciante de demarcar a própria identidade poética.

Todas as hipóteses têm sua plausibilidade, afinal seguindo-se o conceito de dialogismo da linguagem, proposto por Mikhail Bakhtin (1981, 1993, 1997), o que essa estrofe assinala é a natureza dialógica inerente à linguagem em geral e especialmente constitutiva da tradição do discurso literário. Por natureza dialógica, Bakhtin assinala o aspecto absolutamente social que a língua possui, enquanto instrumento central da elaboração e compartilhamento de ideias que fundam e sustentam a própria sociedade dos homens. Todo enunciado individual se inscreve num sistema coletivo mais amplo de linguagem, respondendo de algum modo a algo que foi dito anteriormente, num diálogo infinito e sempre aberto:

O enunciado é um elo na cadeia da comunicação verbal. Tem fronteiras nítidas, determinadas pela alternância dos sujeitos falantes (dos locutores), mas dentro dessas fronteiras, o enunciado, do mesmo modo que a mônada de Leibniz, reflete o processo verbal, os enunciados dos outros e, sobretudo, os elos anteriores (às vezes os próximos, mas também os distantes, nas áreas da comunicação cultural). (Bakhtin 1997: 319)

Por outro lado, cada texto é "individual, único e irrepetível" (idem: 331), pois responde a condições singulares, específicas, que demandaram sua produção e o fizeram existir e assumir uma perspectiva definida a partir do universo social e dialógico do pensamento humano e, assim, nele inserida. Portanto, "um enunciado é sulcado pela ressonância longínqua e quase inaudível da alternância dos sujeitos, falantes e pelos matizes dialógicos, pelas fronteiras extremamente tênues entre os enunciados e totalmente permeáveis à expressividade do autor" (idem: 318). Bakhtin apontava ainda que: "As formas 
de reações-respostas que preenchem o enunciado são sumamente variadas [...]" (idem: 317).

Propõe-se aqui tomar a colagem torquatiana como uma reação-resposta preferencial do escritor às vozes que de algum modo o interpelam e o estimulam a tomar uma posição enquanto artista da linguagem. Afinal, Torquato constituiu-se como poeta nos anos já de descenso do projeto modernista, mas o mito da originalidade criativa (criado pelo Romantismo e herdado pelo Modernismo) ainda se impunha de modo hegemônico como critério máximo de valoração da poesia e da arte em geral. Cabia-lhe responder de algum modo à nítida compreensão de que as vozes dos autores que leu estavam inevitavelmente pairando sobre sua criação, habitando sua própria voz poética, que - em "Poeminha só de brincadeira" - externa o desconforto diante do que seria seu papel de "mero imitador".

O poeta responde ao impasse com um notável estratagema, precisamente perpassado pela apropriação do texto alheio, fazendo ecoar Alice no País das Maravilhas, na cena em que três jardineiros tentam se safar da colérica Rainha de Copas com um inusitado ardil, pintar rosas brancas com a cor vermelha - ou cor de carmim, como ficou consagrada na tradução brasileira da animação longa-metragem realizada pelos estúdios Disney, com base no texto de Carroll, em 1951: E o sacripanta/ da santa/ do altar/ de jacarandá/ pintou os canecos/ da cor/ de carmim// (Qual é a cor do carmim?) (Neto 2004a: 41)

Nessa reação-resposta à censura presente na terceira estrofe, a voz poética toma para si, pois, com a alcunha de sacripanta (um enganador, um trapaceiro, um fingido) que Ihe fora impingida. A ideia é ainda reforçada pela alusão à expressão bem brasileira da "santa do pau oco", isto é, alguém que aparenta ser o que não é. A citação ao artifício armado pelos jardineiros de Alice completa assim um elenco várias de figuras de dissimulação e disfarce, acumuladas em poucos versos. Certamente, não haveria de ser coincidência que todas estas citações envolvam algum tipo de ocultamento: nem a santa do pau oco, nem o texto de Carroll são colocados explicitamente ao leitor, eles se entremostram, se camuflam nas artimanhas do poeta. E assim, matreiramente a fala do sujeito poético toma a voz alheia como se fosse a sua; incorporando o outro, o eu-lírico torquatiano finge ser o que não é, para acabar se tornando quem deseja ser, assinalando a inescapável presença do outro no cerne mesmo da identidade do poeta. Não que o dilema 
se resolva por completo, já que no último verso, a impertinente voz crítica posta outra vez entre parênteses, provoca - "qual é a cor do carmim?"- e repõe o debate sobre o que se é, o que se finge ser e sobre o que deseja ser.

Percebe-se assim que a poética de Torquato recorre constantemente a um misto de vozes, códigos e imagens extraídos de outros textos e contextos, tornando-os elementos de sua própria arte. O uso torquatiano da colagem não foi como uma experiência passageira ou eventual, ligada aos seus dias de Tropicália. Concebidos antes do movimento tropicalista e do surgimento da Ditadura Militar, estes poemas demonstram que a colagem torquatiana não tinha como único motivo a construção paródica ou a crítica política. Ela também estava a serviço da invenção de uma identidade poética, buscada pelo artista desde o final da adolescência até a sua morte precoce.

No caso da poética de Torquato, faria todo sentido responder à questão identitária apropriando-se de outro trecho de Alice: "I know who I was when I got up this morning, but I think I must have been changed several times since then" (Carroll 2007: 48). Afinal, sua poética singular apresenta diversos tipos de atividade escritural, que abarcam gêneros diferentes e revelam uma voz que está em permanente mutação, envolvendo-se constantemente em novas buscas estéticas. Sua obra passa por constantes alterações de padrões formais e códigos, sem se fidelizar a nenhuma delas, transitando do cinema, ao jornal, à canção popular, à televisão, à poesia escrita, etc. Por exemplo, em "Poeminha só de brincadeira", o efeito de poema-piada (lição do mestre Oswald de Andrade) é perfeitamente salientado pela métrica dos versos breves, enquanto as aliterações ressaltando o aspecto lúdico do texto ("Oh! Mero/ imitador/ de Homero"). O conhecimento da tradição formal da poesia em língua portuguesa surge em vários outros momentos, como em "Soneto da contradição enorme": "Faço força em esconder o sentimento/ Do mundo triste e feio que eu vejo./ Tento esconder de todos o desejo/ Que eu não sinto em viver todo o momento// Que passa. Mas que nunca passa inteiro./ Deixa comigo o rosto da lembrança/ E o fantasma de só desesperança/ Que me empurra e de mim me faz obreiro // De sonhos. Faço força em esconder/ Do mundo, a dor, a mágoa e a cabeça/ Que pensa tão-somente em não viver.// Faço força mas sei que não consigo/ E em versos integral eu me derramo/ Para depois sofrer. E então, prossigo" (Neto 2004a: 46). 
Tem-se aqui um poema pensado de acordo com a tradição camoniana da contradição interna do eu cindido, mas também claramente marcado pela dicção sentimental com que os poetas românticos trabalharam a forma do soneto. Nem um pouco tocado pela verve irreverente tropicalista, ele revela um Torquato confessional e imerso em leituras da Geração Mal-do-Século, já claramente seduzido pelo fascínio de se deixar morrer. A desconexão entre o eu-lírico e a vida é expressa nas usuais antíteses, mas também na incomum discrepância entre frases e versos: dois enjambements ousados (colocados entre a primeira e a segunda estrofe, e entre a segunda e a terceira estrofe) cortam a frase de súbito, deixando o fôlego suspenso até pousar na estrofe seguinte. Como se o ritmo do poema estivesse brincando de pular por sobre o abismo, arriscando-se a cair a qualquer momento.

Ainda nesta chave melancólica de incertezas existenciais, o poeta brinca com a forma do hai-kai em "Hai - Kaisinho": "caminho no escuro/ que é/ que eu procuro?" (idem: 53). Ao colocar o nome da tradicional forma japonesa de poesia em diminutivo, Torquato obtém um efeito de ligeira auto-ironia, mas também demarca o ato mesmo pelo qual a voz poética se apropria da voz do outro (no caso, da cultura alheia) e a torna sua. O diminutivo afetivo e familiar deixa clara a intenção de se realizar uma versão torquatiana do hai-kai. No entanto, o poeta trabalha com consciência as aproximações e os deslocamentos em relação à tradição, devorando-a antropofagicamente.

Torquato respeita algumas normas do gênero (Franchetti 2012), como os três versos, a representação do momento presente e a inspiração na natureza física, na concretude da existência transitória - muito embora a marcação temporal de seu poema esteja baseada na oposição binária dia/noite e não no percurso das quatro estações do ano, o que se aproxima mais da natureza dos trópicos. Obtém também harmonia entre clareza de sentido e força sugestiva, dizendo o máximo com o mínimo, mas sem deixar a impressão de um texto elusivo. Certamente o poema tem um ar subjetivo mais intenso do que recomendaria a tradição nipônica, revelando a sempre latente alma romântica da poesia torquatiana, no entanto, sua formulação consegue atingir uma percepção universal, a partir de uma experiência facilmente compartilhada entre os homens, que é a aflição diante da noite profunda. 
Torquato também se dedicou a construir algumas obras inspiradas na Poesia Concreta, principalmente na época em que travou amizade próxima com poetas do movimento. Mais uma vez, não se deixava restringir pelas normas alheias, mas sempre se deixava pautar pela incorporação das vozes que Ihe inspiravam. Per exemplo, o poema "A matéria 0 material 3 estudos de som, para ritmo", escrito no exílio em Paris, nos amargos dias da pós-Tropicália, é dividido em três partes, onde vocábulos geralmente relacionados a elementos do patriotismo vão sendo progressivamente fragmentados, ao ponto da sua quase diluição em pequenos signos soltos no campo da folha de papel - estilhaços para retomar a expressão de Paulo Andrade (2002) - como pode ver na primeira parte do poema: "arco/artefato /vivo /auriverde /sirv / o/ a/ fé/ (ri?)/ da fa/ da,moça/ in/feliz :" (Neto 2004a: 160).

É como se a língua fosse sendo apagada, sendo dilacerada até o limite de seu quase silêncio. O signo verbal é posto mais como objeto visual, do que como palavra capaz de exprimir o mundo dos homens, aliás ecoando o próprio Torquato em "Literato cantabile": "Agora não se fala mais/ Toda palavra guarda uma cilada." (Neto 2004a: 169), poema da mesma época. Os elementos do Concretismo surgem como modo de expressar essa falha da palavra, essa brutal interrupção da conversa entre os homens.

A identidade poética torquatiana é, portanto, uma identidade vampírica, cuja energia vital, cuja força inspiradora, provém do diálogo que o poeta trava com vozes que o interpelam, que lhe provocam a verve póetica. A apropriação surge aí como sua respostareação, como um modo de "entrar na conversa" e apresentar seu próprio ponto de vista, mas numa versão sempre outra do outro e de si mesmo. Não que a consciência do poder do outro sobre o eu seja algo pacífico ou isento de agonia. Ser poeta-vampiro impõe questões morais duras a respeito dos limites entre identidade e alteridade. Em algumas obras, este dilema se coloca como a matéria mesmo do poema. É o caso de "Tema", outro poema da juventude de Torquato, agora baseado na obra de Drummond, no qual o sujeito lírico interpela o personagem de "E agora, José"?, numa arguta brincadeira metalinguística, que revela como a colagem era também um modo de Torquato romper com a admiração excessiva diante da voz alheia uma vez que em excesso tal encantamento periga silenciar o artista que busca ainda se estabelecer: “'...e agora, José? '/ Perguntou Carlos Drummond./ E 
agora, José,/ Responde depressa ao Carlos Drummond./ Responde, José; responde se és homem:/ '... e agora?'/ [...] José do Carlos Drummond:/ Tu és um ladrão./ Roubaste a minha poesia./ Deixaste-me só./ Abandonado, nu./ Sem poesia, sem nada." (Neto 2004a: 38).

Em seu estudo sobre a influência poética ou "a história das relações intrapoéticas", Harold Bloom (2002) defende que o "poeta forte" é o gênio criador cuja obra nasce a partir da apropriação mais visceralmente criativa, mas esta seria justamente aquela que mais se oculta, a que menos se revela, aquela em o poeta-filho parece ter conseguido "matar" a influência do poeta-pai. Segundo este parâmetro, a confissão sincera do sujeito poético de "Tema" indicaria um poeta ainda atordoado demais para conseguir articular outra resposta que não seja uma homenagem-imitação, em consequência é a própria poesia de Torquato que tende a desvanecer, sua própria identidade de poeta arrisca-se a não se definir, ficando à sombra intimidante do poeta Drummond. Já o poema "Bilhetinho sem maiores consequências", onde Torquato pretende corrigir "Dia da criação", de Vinícius de Moraes, estabelece uma disputa poética mais intensa, com o jovem artista ousando recriar o poema predecessor: "Uma retificação, meu bom Vinicius:/ Você falou em 'bares repletos de homens vazios'/ e no entanto se esqueceu/ de que há bares/ [...] cheinhos (ao contrário)/ de homens cheios./ [...]/ E você/ que os conhece tão de perto/ Vinicius 'Felicidade' de Morais/ Não tinha o direito de esquecer/ Essa parcela imensa de homens tristes [...]" (idem: 42)"

Ainda segundo Bloom, Torquato estaria aqui num primeiro nível de batalha poética contra seu antecessor, no passo que ele denomina de "clinamen": "leitura distorcida ou apropriação do mesmo [...]. O poeta desvia-se de seu precursor, lendo o poema dele de modo a executar o clinamen [o desvio] em relação a ele" (2002: 64). Neste ponto, o poetafilho corrige os erros ou falhas do poeta-pai. Neste passo, finalmente estaria se dando o nascimento do poeta Torquato. Seguindo ainda por mais um pouco Bloom, interessa aqui sua compreensão de que o poeta não pode ser um leitor comum, ou seja, um leitor até certo ponto indiferente ou mesmo entregue, de bom grado, ao encanto que a poesia criada fora dele é capaz de produzir. A angústia, e não a simples fruição, é o que se apodera dele - esta angústia é o próprio daemon da poesia e aí o que está em questão não é tão somente a leitura do poema, mas o surgimento - por esta leitura - de um novo sujeito poético, desde agora devedor ao pai que o chamou à existência: 
Quando um poeta em potencial se descobre (ou é descoberto por) a dialética da influência, descobre a poesia como sendo ao mesmo tempo interna e externa a si mesmo, inicia um processo que só acabará quando não mais tiver poesia dentro de si, muito depois de ter o poder (ou desejo) de redescobri-la fora de si. Embora toda essa descoberta seja um auto-reconhecimento, na verdade um Segundo Nascimento [...] é ato jamais completo em si. [...] Pois o poeta está condenado a aprender seus mais profundos anseios através da consciência de outros eus. O poema está dentro dele, mas ele sente a vergonha e o esplendor de ser descoberto por poemas - grandes poemas - fora dele. Perder a liberdade nesse cento é jamais perdoar, e aprender para sempre o pavor da autonomia ameaçada. (idem: 75-76)

Pode-se concluir assim, que a colagem torquatiana apresenta-se também quando o poeta busca elaborar sua própria identidade lírica, apropriando-se de conceitos e imagens elaborados por outros autores, promovendo um curto-circuito na premissa da originalidade artística, herdada dos românticos pelos modernistas. Embora não se negue a luta agônica do poeta para constituir sua própria voz, por outro lado também pode-se afirmar que não chega a haver um pavor assombroso na poética torquatiana quanto a assumir e incorporar os outros "eus" de que Bloom fala.

O terror de ter "a autonomia ameaçada" supostamente se estenderia de modo mais agudo aos poetas de sociedades marginais, como a brasileira, pouco autônoma desde a origem, aliás. Entretanto, é possível que esse medo de reconhecer o outro como origem do sujeito tenha sido em grande parte retrabalhado e redimensionado pelo eu poético torquatiano através da proposta da Antropofagia cultural, que, por sinal, teve como estímulo justamente o anseio de subverter a condição de imitadores ou assimiladores que caberia aos poetas e pensadores fora do centro europeu. Uma boa pista para balizar esta discussão pode estar no poema "Dia", em que Torquato recria um clássico do cânone literário ocidental, mobilizando diversos mitos ancestrais para elaborar uma reflexão sobre o nascimento e as relações entre o pai/velho e o filho/novo.

Ainda que sofra algumas atualizações (o homem tem roupas típicas da contemporaneidade), a primeira estrofe mantém o tom solene do discurso mítico grego, enquanto retoma a antiga narrativa heroica do dia que nasce, após intensa batalha, contra as trevas da noite (cf. Durand 2002 90-111): “Na praça enorme/ sozinho, o homem/ quase grisalho/ sapatos pretos /camisa branca/ gravata velha /terno surrado,/ com mãos potentes/ 
o filho do dia/ arranca às pressas/ da noite mãe/ e suspendendo-o/ o mostra ao mundo." (Neto 2004a: 47). No poema, cabe à figura paterna a função de protetor, afinal é ele quem arrebata o recém-nascido do caos primordial do ventre materno, assim é ele quem garante que o menino ganhe existência separada da mãe, cuja natureza nictomórfica indica a imprecisão algo horripilante dos não nascidos, isto é, das existências que nem se formam reduzidas a puras sombras.

A pouco usual seriedade da voz poética torquatiana, nesta estrofe, dá lugar à ironia na segunda e terceira estrofes, sem que se perca em nada a sensação aflitiva que acompanha todo o poema. Pelo contrário, ela se intensifica, na medida em que uma cena análoga se desenrola (de modo tão similar que só pode ser uma duplicação em negativo da primeira), enquanto a figura paterna passa de protetora a ameaçadora: "Na mesma praça/ num outro banco/ sozinho, um homem/ pega o fedelho/ com mãos cansadas,/ abre-Ihe os olhos/ e em voz pausada/ lança-Ihe à cara/ seu desafio/ mais derradeiro/ 'Ou me decifras/ ou me devoras,/ menino chato.'” (idem: 47) Muito embora a conclusão do poema surja num arremedo abusado do enigma da Esfinge, o que se articula aqui é o mito de Cronos, aquele em que o pai devorava os filhos para impedi-los de tomarem seu trono.

Pode-se considerar então que o medo de não nascer, o medo de não vingar, o medo de não se constituir participam sim do horizonte do poeta Torquato, que lida, no poema em análise, lida com seus temores por meio de um progressivo rebaixamento do mito, que começa na versão modernizada, passa pelo sarcasmo e desagua no deboche algo iconoclasta. O modo atrevido pelo qual o poeta se apropria da tradicional fala da Esfinge (que, por sua vez, remete a Édipo) retoma outra vez a fórmula parodística e, se não chega a anular a sensação de terror diante da fragilidade da vida, suspende-a brevemente pelo riso. Descontrai-se a tensão quando o poeta ousa desmontar seus ídolos e, em resposta ao medo de ser devorado, põe-se ele mesmo a devorar com sua peculiar irreverência. Parece que esta é a marca da antropofagia de Torquato: um modo de ser poeta que se constitui por meio de um devoramento, geralmente sério-cômico, no qual o eu poético não oculta seus atos de absorção de outros eus, ao contrário, absorve-os à plena vista e extrai deles sua força existencial, num vampirismo em relação ao texto alheio. 
Possivelmente, o maior exemplo desta absorção da identidade alheia possa ser identificada na canção "Lets play that", musicada e gravada por Jards Macalé (1972). A lógica tropicalista já se revela no recurso ao anglicismo presente no título, mas é na intertextualidade com o "Poema de sete faces", um dos mais conhecidos de Carlos Drummond de Andrade, que ganha feição tipicamente torquatiana. Diziam os versos de Drummond: "Quando eu nasci, um anjo torto/ desses que vivem na sombra/ disse: Vai, Carlos! ser gauche na vida", numas das passagens que melhor articula o sujeito lírico drummondiano. Curiosamente, a versão torquatiana também se consagrou como um dos mais importantes poemas de sua obra, adquirindo profunda identificação com a mítica do poeta piauiense, mesmo diante da notoriedade da apropriação:

\author{
Quando eu nasci \\ Um anjo louco muito louco \\ Veio ler a minha mão \\ Não era um anjo barroco \\ Era um anjo muito louco, torto \\ Com asas de avião \\ Eis que esse anjo me disse \\ Apertando minha mão \\ Com um sorriso entre dentes \\ Vai bicho desafinar \\ O coro dos contentes. (Neto 2004a: 131)
}

A apropriação se sustenta como criativa uma vez que fica evidente todo um instigante jogo de afastamento e aproximação, que permite a Torquato apossar-se da fala drummondiana. O anjo torquatiano remete ao suspeito e irônico anjo de Drummond, mas os deslocamentos se sucedem, ampliando a carga imagética: não é um anjo barroco (como de Aleijadinho que, por sua vez, altera os belos anjos de Rafael), mas uma criatura própria da pós-modernidade "com asas de avião" (como o traçado urbano de Brasília). Não traz a sofisticação meio blasé do anjo algo afrancesado de Drummond, e sim uma familiaridade feroz ("vai bicho"), com seu sorriso dentado que remete justamente à mítica do vampiro, criatura folclórica incorporada à literatura pelo romantismo gótico como um ser demoníaco próximo do anjo caído Lúcifer. Cuja rede intertextual remete-nos a poetas satanistas do 
século XIX, tais como Lord Byron ou Álvares de Azevedo. Todos devidamente reutilizados pela indústria cinematográfica. Assim, num jogo de múltiplas referências, num caleidoscópio de imagens do anjo maldito, Torquato se apodera da criação de Drummond e a faz tão sua, que o termo "anjo torto" se torna um dos mais utilizados epítetos para identificá-lo (um exemplo bastante demonstrativo é o nome do documentário dirigido por Ivan Cardoso em 1992: Torquato Neto, o anjo torto da Tropicália).

Numa outra característica peculiar à lírica de Torquato, a identidade poética formada através da absorção do outro é constantemente evocada em outros textos dele mesmo, como a reforçar a legitimidade da incorporação. Em sua última crônica publicada na coluna "Geleia geral", em 10 de março de 1972, com o título "na corda bamba", outro anjo sinistro, aparece e tem com ele um diálogo intrigante: "É como se fosse uma história. Começa quando? Ontem: o anjo do bem \& do mal, caído estirado escutando pragas. Ele me contou: sabe que está caído e sabe de todo resto, sabe que morre sozinho conforme plantou, planejou e tenta. Sabe por quê" (Neto 2004b: 379).

O anjo que, de novo circula na rede imagética do satânico e o vampírico, parece ser imortal em sua repetitiva capacidade de morrer, perecendo algumas vezes em poucas linhas da prosa poética torquatiana (aliás, ótimo exemplo de como ele alterou o gênero cronístico, fugindo a qualquer definição convencional). Em comum, todas estas mortes ocorrem na mais absoluta solidão, reforçada insistentemente pela criatura enigmática: "Eu sei que vou morrer sozinho" (ibidem). Ainda outra alusão a "Let's play that" surge na finalização de "na corda bamba": "[...] me despedi do bicho e vim pro rumo do centro da cidade" (idem: 380). A sombra do anjo torto continua assim a se projetar sobre a escritura torquatiana, deixando a exclusiva posição de vidente da trajetória existencial do artista (como é o caso em Drummond), para ocupar também o papel de prenunciador de sua morte: "Repetiu: estou cansado de saber que este cansaço é que me mata, estou sabendo, vou vivendo assim por aí tudo e se você quiser repare, se não quiser esconda o rosto e não olhe mais, feche a porta e tenha coragem de não me deixar entrar mais nunca." (idem: 379).

No entanto, a coluna em si não traz apenas o texto "na corda bamba"; na sequência deste, Torquato divulga, com breves comentários informativos, algumas letras inéditas de Luiz Melodia (músico que Torquato ajudou a revelar para o grande mercado). A divulgação 
de obras de outros artistas era algo constante na "Geleia geral", mas há algo aqui para além da mera propaganda da produção de algum colega de artes, as letras publicadas formam um claro diálogo com "na corda bamba". O mesmo terror existencial que penetra o viver cotidiano pode ser visto nos versos de "Estácio, eu e você": "Vamos passear na praça/ enquanto o lobo não vem/ [...] Vamos circular na praça/ prenda bem este cansaço/ inda vou passar no Estácio" (Melodia, apud Neto 2004b: 380); a solidão de quem luta com a morte dá as caras em "Feras que virão": As feras estão soltas no alto [...]/ as feras vão avançar/ Viro contra o poste/ banco o forte/ venço a morte/ mas a qualquer hora posso parar [...]/ Meus olhos me varejam espinhos/ eu fico quero mostrar/ às feras que precisam carinho/ sozinho quero ficar [...] (idem: 380-381)

Já o sofrimento existencial dá as caras na pungente "Farrapo humano", cuja letra é particularmente perturbadora quando se pensa que o suicídio de Torquato ocorreria alguns meses depois: "[...] sou santo, sou franco/ enquanto não caio não ligo/ me amarro me encarno na sua/ mas estou pra estourar, estourar;/ Eu choro tanto me escondo/ e não digo viro um farrapo/ tento o suicídio/ com caco de telha/ ou caco de vidro [...]" (idem: 381). É como se o poeta, mais uma vez, se valesse da criação alheia para anunciar mesmo seus dilemas mais íntimos, mais caracteristicamente biográficos. O que se coloca como algo muito paradoxal diante de um dos versos de um dos mais conhecidos poemas de Torquato, o poema "Cogito", onde a elaboração da identidade subjetiva é mais fortemente trabalhada:

\author{
eu sou como eu sou \\ pronome \\ pessoal intransferível \\ do homem que iniciei \\ na medida do impossível \\ eu sou como eu sou \\ agora \\ sem grandes segredos dantes \\ sem novos secretos dentes \\ nesta hora
}

eu sou como eu sou 
presente
desferrolhado indecente
feito um pedaço de mim

eu sou como eu sou

vidente

e vivo tranquilamente

todas as horas do fim. (Neto 2004a: 165)

O título "Cogito" é outra colagem, desta vez retirada da conhecida fórmula elaborada pelo filósofo francês René Descartes, "cogito ergo sum" ("penso, logo existo"), uma das fontes seminais do racionalismo moderno, que se desenvolveria desde o Renascimento europeu. Entretanto, Torquato novamente desarticula o pensamento que apropriou, dandonos não o sujeito integral, fechado, completo da lógica cartesiana, nem o sujeito com ilimitada vontade de independência em relação aos demais sujeitos, conforme idealiza Harold Bloom. Andrade já assinalava a peculiaridade do sujeito torquatiano:

[...] o Cogito torquatiano aponta para a existência fragmentada, desagregada e contraditória de quem vive no limiar entre o "existo" e o "não existo", entre a vida e a morte. A valorização do presente é representada em alto grau [...] O "aqui e agora" é o imperativo máximo. O poeta anuncia-se "vidente", vivendo "todas as horas do fim", o que reforça a própria consciência sobre a fatalidade de sua vida e, até certo ponto, sua opção por situações-limite." (Andrade 2000: 31)

Trata-se pois de um sujeito aberto e provisório, como de fato as análises poéticas anteriores apontam, mas como conciliar esse aspecto com a forte declaração da primeira estrofe, onde o eu se define: "eu sou como eu sou/ pronome / pessoal intransferível"? Outra vez, a própria escrita de Torquato pode esclarecer sua estratégia. Uma curta crônica sua, também publicada na "Geleia geral" assume justamente o título "pessoal intransferível":

Escute, meu chapa: um poeta não se faz com versos. É o risco, é estar sempre a perigo sem medo, é inventar o perigo e estar sempre recriando dificuldades pelo menos maiores, é destruir a linguagem e explodir com ela. Nada nos bolsos e nas mãos. Sabendo: perigoso, divino, maravilhoso. Poetar é simples, como dois e dois são quatro sei que a vida vale a pena etc. Difícil é não correr com os versos debaixo do braço. Difícil é não cortar o cabelo quando a barra pesa. Difícil, pra quem não é poeta, é 
trair a sua poesia, que, pensando bem, não é nada, se você está sempre pronto a temer tudo, menos o ridículo de declamar versinhos sorridentes. E sair por aí, ainda por cima sorridente mestre de cerimônias, "herdeiro" da poesia dos que levaram a coisa até o fim e continuam levando, graças a Deus. E fique sabendo: quem não se arrisca não pode berrar. Citação: leve um homem e um boi ao matadouro. O que berrar mais na hora do perigo é o homem, nem que seja o boi. Adeusão. (Neto 2004b: 227)

Mais uma vez Torquato lança mão de imagens criadas alhures, como é o caso das letras dos ex-parceiros Caetano Veloso e Gilberto Gil ("Nada no bolso ou nas mãos" é um verso de "Alegria, alegria", de Veloso; enquanto o lema "Divino maravilhoso" intitula canção de Gil e Veloso, cantada por Gal Costa). Como está claro, trata-se de um manifesto estético, uma síntese do conceito que Torquato tem da poesia e do poeta. E também está claro como o "pessoal intransferível" fala de uma escolha a ser tomada entre escolhas possíveis, e não de um eu exclusivamente recolhido a si como mônada. É uma concepção do poeta como um sujeito que responde também à existência no tempo histórico, acolhendo em si, simultaneamente, as dimensões coletiva e individual do viver humano.

O que nos remete à noção da vida de cada indivíduo como um texto que pode ser lido pelo outro, quando pensada como uma reação-resposta ao mundo social-histórico em que habitamos: "O ato humano é um texto potencial e não pode ser compreendido (na qualidade de ato humano distinto da ação física) fora do contexto dialógico de seu tempo (em que figura como réplica, posição de sentido, sistema de motivação)" (Bakhtin 1997: 334).

A biografia de Torquato também foi devorada pelo seu sujeito poético. Os constantes embates com seus fantasmas interiores alimentaram a produção de parte significativa de sua obra. Em seus diários e cadernos de anotação, registrava toda espécie de texto que conseguia externalizar, em forma de versos ou numa prosa bastante fluida e, não raro, fragmentos incompletos, compondo um misto de gêneros diversos. Segundo o organizador da mais recente edição das obras completas do poeta, Paulo Roberto Pires: "Torquato Neto escrevia compulsivamente - e não apenas profissionalmente. Mantinha diversos cadernos, pastas com material datilografado, anotações" (2004: 293). E são justamente esses textos híbridos, e até precários, que explicitam como é tênue a linha entre sua faceta de poeta de resistência e sua quase mítica faceta de poeta maldito, cuja arte não se separa claramente 
da vivência biográfica. Vale recordar que, durante a produção de Nosferato no Brasil, Torquato viveu tão intensamente seu papel de vampiro que não despia nem o figurino, nem o personagem, quando do fim das filmagens.

Daí não admira que constantemente ele retome a si mesmo, retrabalhando vez após vez uma mesma expressão ou conceito, em diferentes gêneros de produção textual, dissolvendo ainda mais as fronteiras entre as diferentes modalidades pelas quais se constitui sua arte poética. Assim, o título da canção "Geleia geral é também o título de sua coluna no jornal Última Hora. Uma primeira versão de "Let's play that" surgiu, ainda sem parceria musical na crônica de mesmo título e, por sua vez, os versos "Vai bicho desafinar/ O coro dos contentes" também aparecem na crônica intitulada "Literato cantabile", que é também o título de um poema. A ideia de que o poeta (ou a poesia) é a mãe das artes e das manhas surge em mais de um poema e também na crônica "é só de brincadeira, não dói". Os versos "você me chama/ eu quero ir pro cinema" aparecem no poema sem título e no poema "Go back". O poema "Coro misto fotogênico" é reinventado ao modo concretista no poema "arena a: festivaia - gb". Poderiam ser elencados ainda uma série de exemplos, mas estes já deverão ser suficientes para se perceber o labirinto de espelhos por meio do qual o sujeito poético torquatiano se inventa se dá a conhecer.

A respeito da poética torquatiana, levanta-se aqui a hipótese de que não se pode compreendê-la em sua essência se for realizada uma separação entre o poético, ou o fictício, e o biográfico, pois uma dimensão interfere na escrita da outra e juntas completam uma estética singular que consiste em de representar na arte a própria vida e fazer da vida um espaço de arte. A já mencionada crônica "Literato cantabile", reforça o aviso presente em "pessoal intransferível" contra os possíveis traidores da poesia, os que não seriam capazes de morrer ou viver pelo que escrevem: "Poesia. Acredite nela e viva. E viva ela. Morra por ela se você se liga, mas, por favor, não traia. O poeta que trai sua poesia é um imbecil completo e morto. Resista, criatura" (Neto 2004b 305).

Torquato manifesta sua crença na função libertária da criação poética, cuja arma de resistência é a poesia mesma, vista como uma operação de liberação da linguagem e, portanto, do humano. Para ele é preciso inventar as próprias maneiras de ser, inclusive nos momentos em que o direito de "escreviver" é podado pela opressão da censura. Esse 
posicionamento fica claro na primeira estrofe deste poema sem título: "O Poeta é a mãe das Artes/ \& das armas em geral:/ quem não inventa as maneiras/ do corte no carnaval (alô, malucos) é traidor/ da poesia: não vale nada, lodal" (Neto 2004: 172).

Segundo Diana Klinger, observa-se nos últimos anos um "movimento de retorno à problemática do sujeito" (2007: 36) em estudiosos como Paul Ricoeur, Giorgio Agamben ou Slavoj Zizek, que buscam encontrar "um meio-termo entre desconstrução e hipóstase do sujeito" (ibidem). A estudiosa apresenta vários escritores em que se faria necessário, sim, empreender alguma forma de investigação biográfica, na medida em que um dobrar sobre si mesmo demarca suas obras ficcionais. Concordando com Hal Foster, Klinger aponta que o recente retorno do autor coincide com o "retorno do real", mas não segundo o real substancial, e sim a partir do conceito de real proposto pelo psicanalista Jacques Lacan.

Assim, “[...] não seria um retorno de um sujeito pleno no sentido moderno, cartesiano, mas haveria um deslocamento: "nas práticas contemporâneas da 'literatura do eu' a primeira pessoa se inscreve de maneira paradoxal num quadro de questionamento da identidade"(idem: 39). Posição esta que nos remete ao "Cogito" torquatiano e sua vivência intensa do sujeito fracionado. Entretanto, é sobretudo na definição de autoficção proposta por Klinger que se encontra um postulado extremamente pertinente à obra de Torquato, inclusive pelo que ressalta do elemento performático, tão marcante na vida do poeta:

Concebemos a autoficção como um discurso que não está relacionado com um referente extra-textual (como no caso da autobiografia), mas também não está completamente desligado dele. A autoficção participa da criação do mito do escritor, uma figura que se situa no interstício entre a "mentira" e a "confissão". A noção do relato como criação da subjetividade, a partir de uma manifesta ambivalência a respeito de uma verdade prévia ao texto, permite pensar [...] a autoficção como uma performance do autor. (idem: 55)

Torquato, com sua estética tropicalista e contemporânea, segue essa tendência, inserindo marcas biográficas em toda sua criação poética, sejam elas canções, escritos dispersos ou manifestos disfarçados de crônicas. Já nos diários, correspondências e cadernos de anotações, textos mais imediatamente aceitos como escritas autobiográficas, a mítica de si mesmo prossegue sendo elaborada em imagens assinaladamente poéticas, que não raro são apropriadas pelo seu discurso literário, propriamente dito. A obra torquatiana é 
composta neste constante autodevoramento, em que as crônicas contêm poemas, que por vezes foram também recriados como canções, mas que surgiram em anotações de cadernos, diários ou, até mesmo, durante uma correspondência com um amigo do exterior. Assim, o autor busca unir poesia e vida: "Poesia. Acredita nela e viva. E viva ela" (Neto 2004b: 304).

No caso de Torquato, pensar em sua obra independente da sua influência enquanto autor é impossível. Ele não é apenas um escritor responsável por inserir discursos numa sociedade. Ele carregou em seu próprio corpo (nas roupas-figurinos, nos gestos excêntricos e grandiosos, nas várias versões de si) o protesto contra os valores difundidos pela Ditadura Militar. Ele se deixou confundir com a própria mítica que tecia ao seu redor, incorporando o vampiro tropical, ridículo e doloroso, símbolo macabro de um movimento solitário em que intimidade e política são indistinguíveis.

\section{Bibliografia}

Andrade, Paulo (2002), Torquato Neto: Uma poética de estilhaços, São Paulo, Annablume/FAPESP.

Bakhtin, Mikhail (1993), A cultura popular na Idade Média e no Renascimento: o contexto de François Rabelais, trad. Yara Frateschi, São Paulo, Hucitec.

-- (1997), Estética da criação verbal, trad. Paulo Bezerra, 2. ed., São Paulo, Martins Fontes.

--(1981), Problemas da poética de Dostoiévski, trad. Paulo Bezerra, Rio de Janeiro, ForenseUniversitária.

Bloom, Harold (2002), A angústia da influência: uma teoria da poesia, trad. Marcos Santarrita, 2. ed., Rio de Janeiro, Imago. 
Carroll, Lewis (2007), Alice's Adventures in Wonderland, MacMillian \& Company / Open Books Electronic Edition.

Favaretto, Celso Fernando (2000), Tropicália: Alegoria, alegria, 3. ed., Cotia, São Paulo, Ateliê Editorial [1979].

Franchetti, Paulo (org.) (2012), Haikai: antologia e história, 4. ed., Campinas, Editora da Unicamp.

Gaspari, Elio (2002), A ditadura envergonhada, São Paulo, Companhia das Letras.

Gil, Gilberto / Neto, Torquato (2005), "Geleia geral", in Tropicalia ou Panis e circensis, 1 Compact Disc, arranjo e regência de Rogério Duprat, Rio de Janeiro, Universal Music [1968], faixa $6(3 \min 42)$.

Hollanda, Heloísa Buarque de (2004), Impressões de viagem: CPC, vanguarda e desbunde: 1960/70, Rio de Janeiro, Aeroplano.

Jameson, Fredric (1985), "Pós-Modernidade e Sociedade de Consumo", Novos Estudos, n. ${ }^{\circ}$ 12, CEBRAP: $16-26$.

Klinger, Diana (2007), Escritas de si, escritas do outro: o retorno do autor e a virada etnográfica, Rio de Janeiro, 7 Letras.

Machado, Gláucia Vieira (2005), Todas as horas do fim: Sobre a poesia de Torquato Neto, Maceió, Edufal.

Neto, Torquato (2004a), Torquatália - Do lado de dentro, Rio de Janeiro, Rocco.

-- (2004b), Torquatália - Geleia geral, Rio de Janeiro, Rocco.

Pignatari, Décio (2012), "Torquato Neto: Conversa entre Décio Pignatari e Régis Bonvicino", Sibila, <http://sibila.com.br/critica/torquato-neto-conversa-entre-decio-pignatari-e-regisbonvicino/8578> (último acesso em 11/03/2016).

Rezende, Maria José de (2001), A Ditadura Militar no Brasil: Repressão e pretensão de legitimidade 1964-1984, Londrina, Editora UEL.

Sant'Anna, Afonso Romano de (2003), Paródia, paráfrase \& cia, 7. ed., São Paulo, Ática. 
Elzimar Fernanda Nunes Ribeiro é Doutora e Mestre em Literatura Brasileira pela Universidade de Brasília (UnB), atuando como professora permanente na Universidade Federal de Uberlândia, desde 2009. Tem desenvolvido e orientado pesquisas, na graduação e na pós-graduação, relacionadas à produção poética brasileira no período da Ditadura Militar, a partir do estudo de como as imagens de medo e violência deixaram marcas sobre a criação literária deste período. Integra o grupo de pesquisa POEIMA - Poesia e Imaginário, do qual é vice-líder desde 2011.

Pâmella Pereira Magalhães é Mestranda em Teoria Literária pela Universidade Federal de Uberlândia (UFU), tendo como orientadora a Profa. Dra. Elzimar Fernanda Nunes Ribeiro. Desenvolve pesquisas sobre a obra de Torquato Neto desde a graduação, quando foi bolsista de PIBIC, apresentando trabalho sobre o caráter híbrido, entre crônica e poesia, dos textos publicados na "Geleia geral". Atualmente, encontra-se finalizando a Dissertação de Mestrado, intitulada "O imaginário do heroico e do monstruoso na poética de Torquato: $\mathrm{O}$ fascínio pelo misterioso", com previsão de defesa em julho de 2016. 